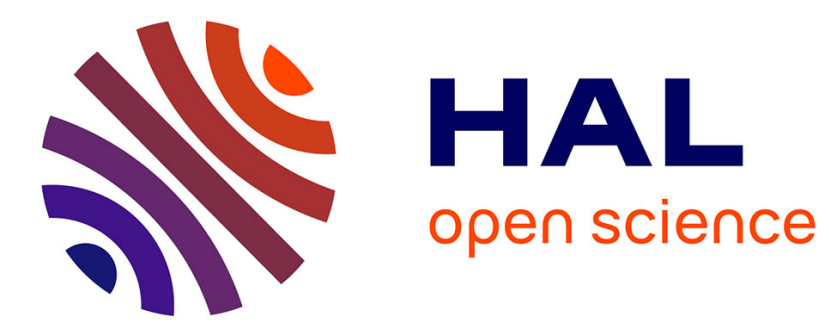

\title{
Sorption and leaching of 14C-glyphosate in agricultural soils
}

\author{
Abdul-Jabbar Al-Rajab, Samira Amellal, Michel Schiavon
}

\section{To cite this version:}

Abdul-Jabbar Al-Rajab, Samira Amellal, Michel Schiavon. Sorption and leaching of 14Cglyphosate in agricultural soils. Agronomy for Sustainable Development, 2008, 28 (3), pp.419-428. 10.1051/agro:2008014 . hal-02663349

\section{HAL Id: hal-02663349 \\ https://hal.inrae.fr/hal-02663349}

Submitted on 31 May 2020

HAL is a multi-disciplinary open access archive for the deposit and dissemination of scientific research documents, whether they are published or not. The documents may come from teaching and research institutions in France or abroad, or from public or private research centers.
L'archive ouverte pluridisciplinaire HAL, est destinée au dépôt et à la diffusion de documents scientifiques de niveau recherche, publiés ou non, émanant des établissements d'enseignement et de recherche français ou étrangers, des laboratoires publics ou privés.

$$
\text { Copyright }
$$




\title{
Research article
}

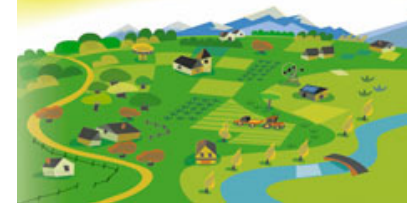

\section{Sorption and leaching of ${ }^{14} \mathrm{C}$-glyphosate in agricultural soils}

\author{
Abdul Jabbar AL-RAJAB, Samira AMELlal, Michel SchIAVON* \\ Laboratoire Sols et Environnement, UMR 1120 INPL/ENSAIA-INRA, 2 avenue de la Forêt de Haye, BP 172, 54505 Vandœuvre-lès-Nancy Cedex, France
}

(Accepted 28 February 2008)

\begin{abstract}
Glyphosate ( $N$-(phosphonomethyl)glycine) is one of the most widely used herbicides in the world to control weeds in agricultural and urban areas. Its increasing use requires special attention to its transfer from terrestrial to aquatic environments. However, knowledge on the leaching of glyphosate and its metabolite aminomethylphosphonic acid (AMPA) is scarce. Here we aimed to assess the dynamic interactions between glyphosate sorption and leaching; and to identify the main factors that influence the two processes in three undisturbed agricultural soils using microlysimeters under outdoor conditions. We studied the sorption, desorption and leaching of ${ }^{14} \mathrm{C}$-labelled glyphosate on three soils using batch experiments in the laboratory and lysimeters under natural conditions for 11 months. The laboratory results showed that glyphosate was strongly adsorbed, yielding empirical constants of Freundlich sorption isotherms $\left(\mathrm{K}_{\mathrm{f}}\right)$ of 16.6 for the clay loam soil, 33.6 for the silt clay loam soil and 34.5 for the sandy loam soil, with $\mathrm{n}_{\mathrm{f}}$ close to 1 in all three cases. Glyphosate was also weakly desorbed, i.e. 5 to $24 \%$ (w) of initially sorbed glyphosate. Sorption and desorption were only pH-dependent. The outdoor results showed that nearly $70 \%$ of the initial glyphosate was present in the soil in a non-extractable form at the beginning of the experiment. Conversely, only less than $20 \%$ of the initial glyphosate is present in the soil in a non-extractable form after 11 months. These findings suggest that the non-extractable residues become available and take part in biodegradation and leaching. The amounts of ${ }^{14} \mathrm{C}$-glyphosate derivatives leached were less than $0.28 \%$ of the initially applied glyphosate. HPLC analyses showed that the AMPA metabolite generally represented up to $100 \%$ of the residues present in the leachates. The results of leaching were highly influenced by the hydrodynamic properties and the biodegradation capacities of the soils. Although glyphosate residues were found in low concentrations in the leachates for almost a year, the contamination of groundwater does not seem to be a concern, regardless of the soil type, if the herbicide is used in accordance with good agricultural practice.
\end{abstract}

glyphosate / adsorption / desorption / leaching / sequestration / persistence / soil lysimeters

\section{INTRODUCTION}

Changes in cultivation methods with minimal or no working of the soil mean that farmers are using increasing amounts of glyphosate to clean their fields before planting. The lack of damage to crops planted immediately after treatment is apparently due to the rapid inactivation in the soil of this non-selective systemic herbicide which is absorbed by the foliage. Inactivation is thought to be the result of strong sorption of the molecule to soil components (Sprankle et al., 1975; Autio et al., 2004) and rapid degradation by soil microorganisms. Because of its strong sorption and rapid degradation, glyphosate is not supposed to cause environmental problems or affect the quality of the water resource (Laitinen et al., 2006; Mamy and Barriuso, 2005). However, not many studies have been undertaken under outdoor conditions (De Jonge et al., 2000; Fomsgaard et al., 2003; Kjaer et al., 2005) and they are not easy to compare because of different experimental conditions, and climate and/or soils whose consequences

*Corresponding author: michel.schiavon@ensaia.inpl-nancy.fr are difficult to assess. In addition, the results of these studies vary and are sometimes conflicting. Even the results of studies conducted in the laboratory (Doliner, 1991; Dousset et al., 2004) do not agree, although they tend to show weak leaching of glyphosate. However, this herbicide and its metabolite aminomethylphosphonic acid (AMPA) are frequently found in surface water and even in groundwater (IFEN, 2006) at concentrations above the EC limit of $0.1 \mu \mathrm{g} / \mathrm{L}$. In fact, the data in the literature concerning the leaching of glyphosate and AMPA partially reflect the complexity of the interactions of the processes that influence leaching such as adsorption, desorption, degradation, sequestration, hydrodynamic properties of the soils and climatic conditions. In this context, the aims of this work were to assess the dynamic interactions between glyphosate sorption and leaching and to identify the main factors that influence the two processes. To this end, an experiment was carried out under natural climatic conditions using microlysimeters with two objectives: (1) to examine the leaching of glyphosate and AMPA in three agricultural soils with contrasting properties, and (2) to provide information 
Table I. Principal characteristics of the soils (surface layers, 0-25 cm) used in this study

\begin{tabular}{|c|c|c|c|c|c|c|c|}
\hline Soil & $\begin{array}{c}\text { Clay } \\
\%\end{array}$ & $\begin{array}{c}\mathrm{pH} \\
\text { (water) }\end{array}$ & $\begin{array}{c}\mathrm{OC}^{\mathrm{a}} \\
\%\end{array}$ & $\begin{array}{c}\text { Fe oxides } \\
\left(\mathrm{g} \mathrm{kg}^{-1}\right)\end{array}$ & $\begin{array}{c}\text { Amorphous } \mathrm{Fe}^{\mathrm{c}} \\
\left(\mathrm{g} \mathrm{kg}^{-1}\right)\end{array}$ & $\begin{array}{l}\text { Total } \mathrm{Cu}^{\mathrm{d}} \\
\left(\mathrm{mg} \mathrm{kg}^{-1}\right)\end{array}$ & $\begin{array}{c}\text { Total } \mathrm{P}_{2} \mathrm{O}_{5} \\
\left(\mathrm{~g} \mathrm{~kg}^{-1}\right)\end{array}$ \\
\hline Sandy loam & 10.5 & 5.1 & 0.82 & 9.73 & 2.89 & 7.89 & 1.24 \\
\hline Silt clay loam & 30.6 & 6.3 & 1.45 & 40.05 & 8.52 & 29.80 & 3.24 \\
\hline Clay loam & 34.9 & 7.9 & 1.91 & 33.16 & 2.51 & 14.11 & 2.74 \\
\hline
\end{tabular}

a Organic Carbon content $(\%)$.

${ }^{\mathrm{b}}$ Subtraction of extracted iron by sodium dithionite-citrate and by acid ammonium oxalate.

${ }^{c}$ Extracted iron by acid ammonium oxalate in darkness.

${ }^{\mathrm{d}}$ Dissolved by HF.

concerning the effects of sorption/desorption, degradation and sequestration on leaching of glyphosate residues.

\section{MATERIALS AND METHODS}

\subsection{Chemicals}

[Phosphonomethyl- $\left.{ }^{14} \mathrm{C}\right]$-glyphosate was obtained from ARC-ISOBIO (Belgium) diluted in water. Its specific radioactivity was $385 \mathrm{GBq} / \mathrm{mmol}$ and its radiochemical purity $99 \%$. Non-radioactive glyphosate (purity $98.5 \%$ ) was obtained from CIL Cluzeau (France). $\mathrm{CaCl}_{2} 2 \mathrm{H}_{2} \mathrm{O}$ was purchased from Prolabo (purity 98\%), and FMOC-chloride (purity 99\%), Sodium tetraborate decahydrate (purity $99.5 \%$ ), Potassium hydroxide (purity 86\%) and Potassium dihydrogen phosphate (purity 99.5\%) were obtained from Fluka, Acetonitrile was obtained from SDS (France). All solvents were of highperformance liquid chromatography (HPLC) grade.

\subsection{Selected soils}

The surface layers of three cultivated soils were sampled $(0-25 \mathrm{~cm})$. They were selected on the basis of their texture and pH (Tab. I) (Jacquin and Florentin, 1988). The three soils came from the Lorraine region in eastern France. Soil types were classified as Rendzic leptosol, Fluvic cambisol, and Stagnic luvisol (Batjes, 1998), hereafter referred to as: clay loam soil, sandy loam soil and silt clay loam soil, respectively.

\subsection{Laboratory sorption and desorption experiments}

Soil samples were air-dried, sieved to $0-2 \mathrm{~mm}$, stored in the dark at room temperature $\left(20 \pm 2{ }^{\circ} \mathrm{C}\right)$, and protected from humidity. Sorption experiments were carried out using the standard batch equilibration method (OECD guideline 106, 2000) as described below. According to the results of previous kinetic studies, the soil weight/solution volume ratio was adjusted to $1 / 5(\mathrm{w} / \mathrm{v})$ and the equilibrium was assumed to be reached within the $16 \mathrm{~h}$ equilibration period (results not shown). In the first stage, $10 \mathrm{~mL}$ of aqueous calcium chloride $\left(\mathrm{CaCl}_{2}, 0.01 \mathrm{M}\right)$ were added to $2 \mathrm{~g}$ of air-dried soil sieved to $2 \mathrm{~mm}$, in $16 \mathrm{~mL}$ (Nalgene PPCO) centrifuge tubes, in order to bring the samples to water saturation. The tubes were shaken with a rotary agitator $(60 \mathrm{rpm})$ for $1 \mathrm{~h}$ at $20 \pm 2{ }^{\circ} \mathrm{C}$ in the dark and then centrifuged at $5000 \mathrm{~g}$ for $25 \mathrm{~min}$ using an Avanti ${ }^{\mathrm{TM}} \mathrm{J}-25$ (Beckman Instruments, Inc., Fullerton, CA, USA). Next, supernatants were removed $(8 \pm 0.01 \mathrm{~mL})$ and replaced by labelled ${ }^{14} \mathrm{C}$-glyphosate solutions at $0,0.73$, $1.33,3.13,6.13,12.13,30.13$ and $60.13 \mathrm{mg} / \mathrm{L}$. The radioactivity of all the solutions was $146.5 \mathrm{~Bq} / \mathrm{mL}$. The tubes were then shaken again, using the same conditions as those described above, and then centrifuged as described above. Three replicates were made for each concentration. $10 \mathrm{~mL}$ of a scintillation cocktail (UltimaGold ${ }^{\mathrm{TM}}$, Packard Bioscience) was added to the solution and the radioactivity of the supernatant measured using a 1900 Tri-carb liquid scintillation analyser (Packard). The counting time was 10 min and a quench correction was made by the scintillator analyser after calibration. Several tubes without soil were also shaken as controls. These showed a negligible loss $(0.1 \pm 0.05 \%)$ of ${ }^{14} \mathrm{C}$. Consequently, the differences between the initial and equilibrium concentrations were assumed to be due to sorption onto soil. Sorption isotherms were obtained by plotting the amount of glyphosate sorbed per weight of soil at equilibrium $\left(\mathrm{Q}_{\mathrm{e}}, \mu \mathrm{g} / \mathrm{g}\right)$ versus the amount of glyphosate per volume of solution at equilibrium $\left(\mathrm{C}_{\mathrm{e}}, \mu \mathrm{g} / \mathrm{mL}\right)$. The sorption data were described using the Freundlich equation.

$$
\mathrm{Q}_{\mathrm{e}}=\mathrm{K}_{\mathrm{f}} \cdot \mathrm{C}_{\mathrm{e}}^{\mathrm{nf}}
$$

where $\mathrm{Q}_{\mathrm{e}}$ is the concentration of glyphosate sorbed onto the solid phase $\left(\mu \mathrm{g} \mathrm{g}^{-1}\right), \mathrm{C}_{\mathrm{e}}$ is the concentration of glyphosate in solution at equilibrium $(\mu \mathrm{g} / \mathrm{L})$, and $\mathrm{K}_{\mathrm{f}}$ (in $\mu \mathrm{g}^{1-\mathrm{nf}} \mathrm{mL}^{\mathrm{nf}} \mathrm{g}^{-1}$ ) and $\mathrm{nf}$ are empirical constants which are related to the adsorption phenomenon and calculated by regression analysis. $\mathrm{K}_{\mathrm{f}}$ can be considered as a characterisation of the intensity of sorption, modulated by the deviation from the unity of the $\mathrm{n}_{\mathrm{f}}$ exponent (Coquet, 2002; Saison et al., 2004).

Desorption experiments were conducted immediately after the sorption experiments, starting at a concentration of $2.862 \pm 0.01$ or $115.03 \pm 0.36 \mu \mathrm{g} / \mathrm{g}$ of soil for the clay loam soil, $3.184 \pm 0.09$ or $131.754 \pm 0.23 \mu \mathrm{g} / \mathrm{g}$ for the silt clay loam and $3.183 \pm 0.02$ or $131.748 \pm 0.20$ for the sandy loam soil. First, supernatants were replaced with glyphosate-free aqueous calcium chloride solution $(0.01 \mathrm{M}, 8 \mathrm{~mL})$, and the tubes were shaken at $20 \pm 1{ }^{\circ} \mathrm{C}$ for $16 \mathrm{~h}$. During the preparation of the different replicates, the tubes were stored in the fridge at $5{ }^{\circ} \mathrm{C}$ to avoid bio-degradation. The suspensions were subsequently centrifuged and the radioactivity of the supernatant solution was measured in the same way as for the sorption 


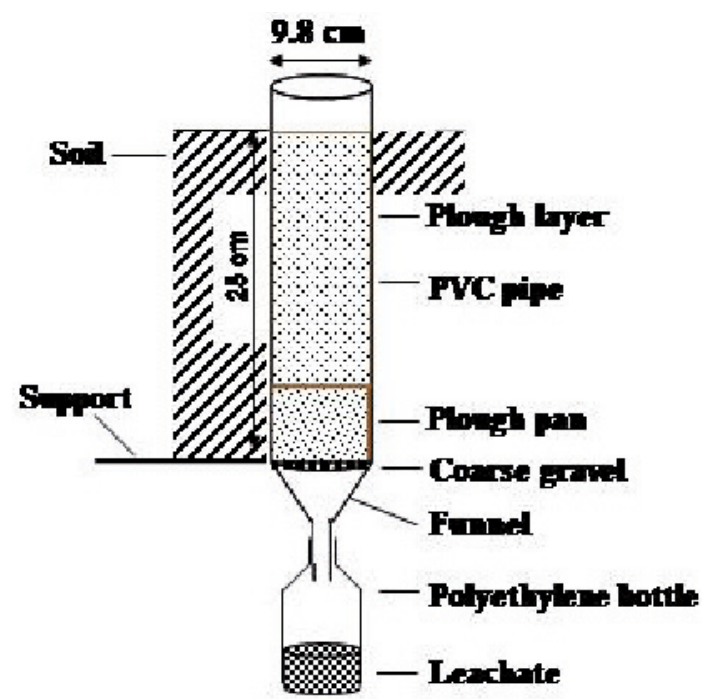

Figure 1. Lysimeter set-up.

experiments. Five successive desorption steps were performed using the procedure described above.

\subsection{Experiment under outdoor conditions}

\subsubsection{Field sampling with lysimeters}

Each lysimeter was a long PVC pipe with an internal diameter of $9.8 \mathrm{~cm}$ and a bevelled base to facilitate soil penetration. This pipe was slowly pushed down into the soil with a hydraulic jack, the soil around the pipe being progressively removed to reduce compaction inside the column. Seven undisturbed soil columns were extracted from each site. The fields sampled had not been sprayed with glyphosate for four years.

\subsubsection{Experimental set-up}

The lysimeters were placed in a large vat located at the ENSAIA experimental site, Vandœuvre-lès-Nancy, France. After placing the lysimeters on their support, the vat was filled with soil to simulate field conditions. The lysimeters were set up three months before the beginning of the experiment and the infiltration rate at saturation was determined at a height of $10 \mathrm{~mm}$ of water (Guennelon, 1994). At the time of the treatment the infiltration rate of the columns was $103.7 \pm 21.8$, $139.6 \pm 34.9$ and $151.8 \pm 44.1 \mathrm{~cm} \mathrm{~d}^{-1}$ for sandy loam, silt clay loam and clay loam, respectively. After treatment, the leachates were collected in polyethylene bottles (Fig. 1).

A total of 21 lysimeters was run for 11 months in outdoor conditions. The experimental site has an oceanic climate with continental influence (average temperature: $10{ }^{\circ} \mathrm{C}$, min: $1.5^{\circ} \mathrm{C}$, max: $18.5^{\circ} \mathrm{C}$; precipitation: $700-900 \mathrm{~mm} /$ year). The sites received natural rainfall ( $869 \mathrm{~mm}$ in 11 months), which generated from 19 to 22 leachates, depending on the soil. After $0,15,30,90,180,270$ and 332 days, a lysimeter was removed for each soil type. The soil columns were frozen before analysis.

\subsubsection{Application rate of glyphosate}

On March 25, 2005, $10 \mathrm{~mL}$ of [Phosphonomethyl- $\left.{ }^{14} \mathrm{C}\right]-$ glyphosate diluted in Roundup Express (isopropylamine salt) (Monsanto Agriculture France, 69-Bron) and water were applied homogeneously to the soil surface with a pipette. This solution supplied $369.26 \mathrm{Kbq}$ and $1.63 \mathrm{mg}$ of glyphosate to each soil column (equivalent to $2160 \mathrm{~g} \mathrm{ha}^{-1}$ or approximately to $2.88 \mu \mathrm{g} \mathrm{g}^{-1}$ of soil present in the top $5 \mathrm{~cm}$ ).

\subsubsection{Collection of leachates}

Leachates were collected from each microlysimeter after each rainfall event. The volume of each individual leachate was measured. The leached radioactivity was counted by liquid scintillation using a Packard TriCarb $2100 \mathrm{TR}(1 \mathrm{~mL}$ of water in $10 \mathrm{~mL}$ of Ultima Gold - Packard) with background noise and quench correction. This measurement allowed quantitative evaluation of the leaching residues (glyphosate and AMPA) for each microlysimeter.

\subsubsection{Extractable ${ }^{14}$ C-compounds in the soils}

A column of each soil was removed $0,0.5,1,3,6,9$ and 11 months after the treatment, and frozen at $-18^{\circ} \mathrm{C}$ for $48 \mathrm{~h}$. The columns were then divided into four segments: $0-5,5-10$, 10-20 and 20-30 cm, air-dried for one week, weighed and carefully crushed prior to sieving through a $2 \mathrm{~mm}$ sieve. Three aliquots of $25 \mathrm{~g}$ were removed from each segment and extracted separately 3 times with $100 \mathrm{~mL}$ of water (easily available residues) then 3 times with $100 \mathrm{~mL}$ of $\mathrm{KH}_{2} \mathrm{PO}_{4} 0.1 \mathrm{M}$. The samples were rotary-shaken at $20 \pm 2{ }^{\circ} \mathrm{C}$ for $2 \mathrm{~h}$ in PPCO centrifuge flasks, and then centrifuged at $5000 \mathrm{~g}$ for $20 \mathrm{~min}$. The supernatants were combined, the volumes adjusted and radioactivity was determined using liquid scintillation as described above.

\subsection{Analysis}

\subsubsection{Derivatisation of residues}

This analysis was carried out only on the leachates and the aqueous soil extracts. $0.5 \mathrm{~mL}$ of buffer borate $0.05 \mathrm{M}$ were added to $3 \mathrm{~mL}$ of the aqueous solution to be analysed, then left to settle for $15 \mathrm{~min}$. Then $3 \mathrm{~mL}$ of ethyl ether were added and the solution was agitated vigorously for $2 \mathrm{~min}$. The mixture was left to settle. After $15 \mathrm{~min}, 1.5 \mathrm{~mL}$ of the aqueous phase was removed and $0.25 \mathrm{~mL}$ of acetonitrile added, followed by $0.25 \mathrm{~mL}$ of a solution of FMOCCI in acetonitrile $(1 \mathrm{~g} / \mathrm{L})$. The mixture was left to react for $60 \mathrm{~min}$ at ambient temperature. Two $\mathrm{mL}$ of ether ethyl were added and the solution was agitated vigorously for $2 \mathrm{~min}$. The solution was left to settle for $1 \mathrm{~h}$ and then the aqueous phase was recovered in a $2 \mathrm{~mL}$ vial for HPLC analysis. 


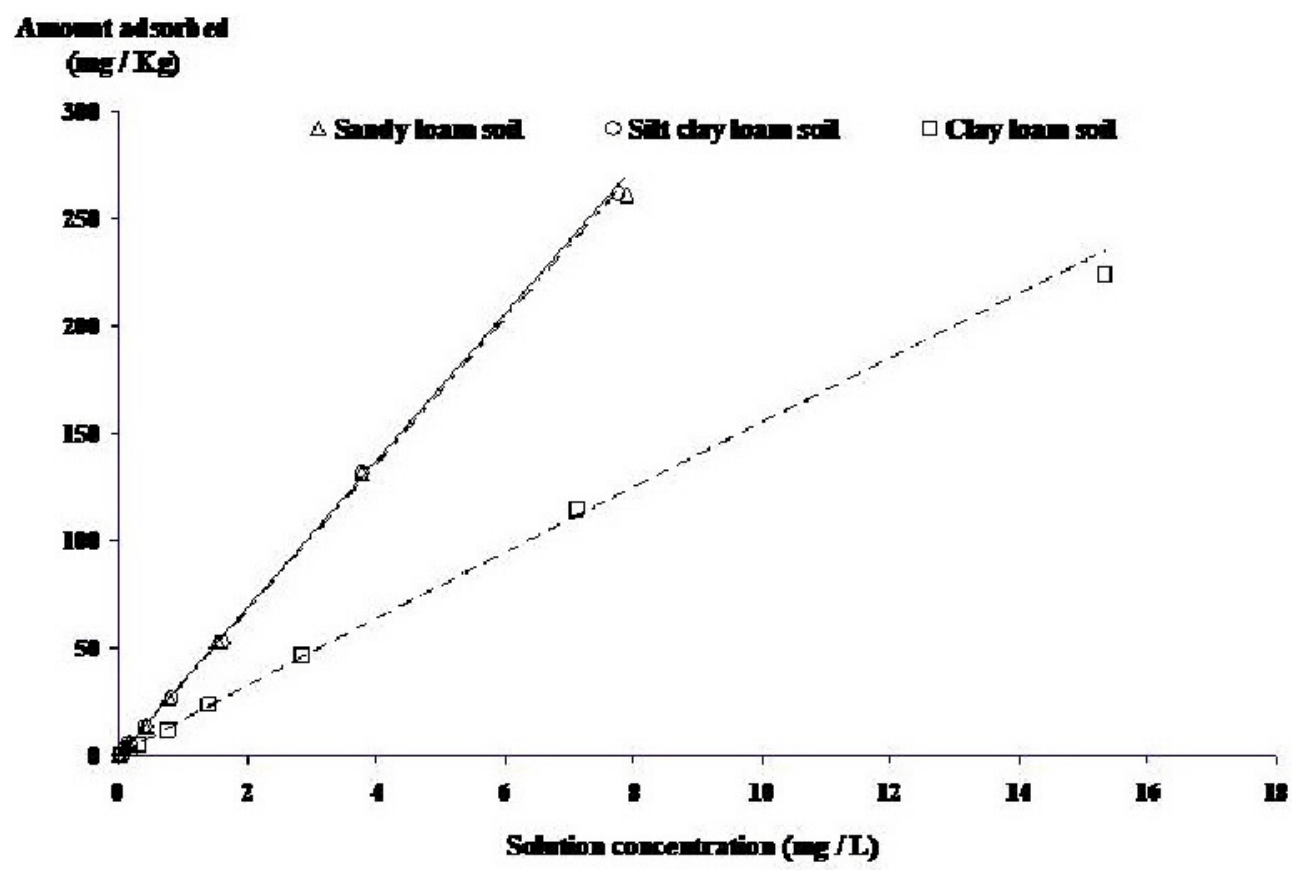

Figure 2. Adsorption isotherms of [Phosphonomethyl- $\left.{ }^{14} \mathrm{C}\right]$-glyphosate for clay loam soil $\left(\mathrm{Qe}=16.6 \mathrm{Ce}^{0.9995} ; \mathrm{r}^{2}=0.999\right)$, silt clay loam soil $\left(\mathrm{Qe}=33.6 \mathrm{Ce}^{1.004} ; \mathrm{R}^{2}=0.999\right)$ and sandy loam soil $\left(\mathrm{Qe}=34.5 \mathrm{Ce}^{0.97} ; \mathrm{r}^{2}=0.999\right)$. (dots: experimental data, lines: Freundlich model $)$. The standard deviation is not visible.

\subsubsection{Analysis of residues}

The residues were analysed by high-performance liquid chromatography (HPLC) in a Varian chromatograph equipped with a fluorescence detector and a $\beta^{-}$radioactivity detector (Flo-one $\beta$, Packard) in the following operating conditions: Lichrosorb- $\mathrm{NH}_{2}$ column $(5 \mu \mathrm{m}, 4 \times 250 \mathrm{~mm}$ ) (CIL-Cluzeau, France) thermostated at $30{ }^{\circ} \mathrm{C}$, injection volume $50 \mu \mathrm{L}$, analysis time $22 \mathrm{~min}$, flow rate $0.8 \mathrm{~mL} \mathrm{~min}{ }^{-1}$, elution $\mathrm{KH}_{2} \mathrm{PO}_{4}$ 0.05 M, pH 5.7 / Acétonitrile (70/30) (v/v). Detection was performed in the following conditions: (1) $\beta$ radioactivity detector: Scintillator Ultima-Flo, flow $1.2 \mathrm{~mL} \mathrm{~min}^{-1}$, counting cell $500 \mu \mathrm{L}$, and (2) fluorescence detector: $\lambda$ excitation $260 \mathrm{~nm} ; \lambda$ emission: $310 \mathrm{~nm}$. Standards of the glyphosate (purity $>98.5 \%$ ), AMPA (purity $>98.5 \%$, CIL-Cluzeau, France) and sarcosine (N-methylglycine, purity $>99 \%$, Fluka) were used for calibration $(0,10,20,50$ and $100 \mu \mathrm{g} / \mathrm{L})$. The retention times were $4.2 \mathrm{~min}$ for sarcosine, $6.6 \mathrm{~min}$ for AMPA and $13.3 \mathrm{~min}$ for glyphosate.

\subsection{Non-extractable radioactivity}

After extraction by water and $\mathrm{KH}_{2} \mathrm{PO}_{4}$, all soil samples were air-dried. Remaining non-extractable ${ }^{14} \mathrm{C}$-radioactivity was determined by combustion. An aliquot of $0.3 \mathrm{~g}$ was mixed with $0.15 \mathrm{mg}$ of cellulose powder and the sample was burnt at $900{ }^{\circ} \mathrm{C}$ with a 307 Packard Oxidiser (Packard). The evolved $\mathrm{CO}_{2}$ was trapped with $10 \mathrm{~mL}$ Carbosorb (Packard) and the radioactivity was counted after the addition of $10 \mathrm{~mL}$ of Permafluor (Packard).

\subsection{Statistics}

Statistics were run using Stat Box computer software (Grimmer Software version 6.4). Comparison of means was made using the Newman-Keuls test at levels of 0.05, 0.01 and 0.001 .

\section{RESULTS AND DISCUSSION}

\subsection{Sorption of glyphosate}

Sorption of glyphosate on soils was studied using the standard batch equilibration method. The glyphosate adsorption isotherms for the clay loam, silt clay loam and sandy loam soils in our working conditions, of $2 \mathrm{~g}$ of soil/10 mL aqueous glyphosate solution, are presented in Figure 2. The high correlation coefficients of $\mathrm{r}^{2}$ higher than 0.999 obtained for the three soils show that the data can be accurately described by the Freundlich model. The values of the $n_{f}$ coefficients are very close to 1 , as described above: 0.999 for clay loam soil, $1.004 \pm 0.02$ for silt clay loam soil and $0.997 \pm 0.01$ for the sandy loam soil. Such values indicate that, under our working conditions, adsorption of the glyphosate is not limited by the number of easily accessible sites when the equilibrium concentration increases (Chiou et al., 2000). Except for certain results obtained by Autio et al. (2004), our results disagree with the majority of those presented in the literature (Mamy and Barriuso, 2005; De Jonge and De Jonge, 1999; Cheah et al., 1997; Glass, 1987). This difference can be explained by the 
Table II. Percentage of glyphosate desorbed during the five desorption steps as a function of the initial quantities adsorbed on the three soils. The letters correspond to the homogeneous groups given by the comparison of means with the Newman-Keuls test $(P<0.05)$.

\begin{tabular}{|c|c|c|c|c|c|c|c|}
\hline \multirow{2}{*}{\multicolumn{2}{|c|}{$\begin{array}{l}\text { Initially sorbed glyphosate } \\
\qquad \mu \mathrm{g} / \mathrm{g}\end{array}$}} & \multicolumn{6}{|c|}{$\begin{array}{c}\text { \% desorbed glyphosate } \\
\text { desorption steps }\end{array}$} \\
\hline & & 1 & 2 & 3 & 4 & 5 & Total \\
\hline \multirow{2}{*}{$\begin{array}{l}\text { Sandy loam } \\
\text { soil, pH: } 5.1\end{array}$} & $\begin{array}{c}3.183 \\
\pm 0.02 \mu \mathrm{g} / \mathrm{g}\end{array}$ & $\begin{array}{c}2.44 \\
\pm 0.23\end{array}$ & $\begin{array}{c}1.56 \\
\pm 0.09\end{array}$ & $\begin{array}{c}1.21 \\
\pm 0.07\end{array}$ & $\begin{array}{c}0.77 \\
\pm 0.09\end{array}$ & $\begin{array}{c}0.60 \\
\pm 0.12\end{array}$ & $6.58 \mathrm{~d}$ \\
\hline & $\begin{aligned} & 131.748 \\
\pm & 0.20 \mu \mathrm{g} / \mathrm{g}\end{aligned}$ & $\begin{array}{c}2.53 \\
\pm 0.03\end{array}$ & $\begin{array}{c}1.86 \\
\pm 0.12\end{array}$ & $\begin{array}{c}1.32 \\
\pm 0.01\end{array}$ & $\begin{array}{c}1.03 \\
\pm 0.07\end{array}$ & $\begin{array}{c}0.63 \\
\pm 0.06\end{array}$ & $7.37 \mathrm{c}$ \\
\hline \multirow{2}{*}{$\begin{array}{l}\text { Silt clay } \\
\text { loam soil, } \\
\text { pH: } 6.3\end{array}$} & $\begin{array}{c}3.184 \\
\pm 0.09 \mu \mathrm{g} / \mathrm{g}\end{array}$ & $\begin{array}{c}1.24 \\
\pm 0.14\end{array}$ & $\begin{array}{c}1.16 \\
\pm 0.07\end{array}$ & $\begin{array}{l}1.15 \\
\pm 0.05\end{array}$ & $\begin{array}{c}0.84 \\
\pm 0.02\end{array}$ & $\begin{array}{c}0.74 \\
\pm 0.07\end{array}$ & $5.13 \mathrm{e}$ \\
\hline & $\begin{array}{r}131.754 \\
\pm 0.23 \mu \mathrm{g} / \mathrm{g} \\
\end{array}$ & $\begin{array}{r}1.75 \\
\pm 0.52 \\
\end{array}$ & $\begin{array}{r}1.79 \\
\pm 0.12 \\
\end{array}$ & $\begin{array}{c}1.37 \\
\pm 0.20 \\
\end{array}$ & $\begin{array}{r}1.23 \\
\pm 0.09 \\
\end{array}$ & $\begin{array}{c}0.77 \\
\pm 0.01 \\
\end{array}$ & $6.91 \mathrm{~cd}$ \\
\hline \multirow{2}{*}{$\begin{array}{l}\text { Clay loam } \\
\text { soil, pH:7.9 }\end{array}$} & $\begin{array}{c}2.862 \\
\pm 0.01 \mu \mathrm{g} / \mathrm{g}\end{array}$ & $\begin{array}{c}8.33 \\
\pm 0.27\end{array}$ & $\begin{array}{c}4.88 \\
\pm 0.20\end{array}$ & $\begin{array}{c}3.67 \\
\pm 0.08\end{array}$ & $\begin{array}{c}2.52 \\
\pm 0.07\end{array}$ & $\begin{array}{c}2.12 \\
\pm 0.05\end{array}$ & 21.52 \\
\hline & $\begin{array}{c}115.032 \\
\pm 0.36 \mu \mathrm{g} / \mathrm{g}\end{array}$ & $\begin{array}{r}10.10 \\
\pm 0.42\end{array}$ & $\begin{array}{c}5.77 \\
\pm 0.10\end{array}$ & $\begin{array}{l}3.81 \\
\pm 0.05\end{array}$ & $\begin{array}{c}2.78 \\
\pm 0.12\end{array}$ & $\begin{array}{c}1.87 \\
\pm 0.13\end{array}$ & $24.33 \mathrm{~b}$ \\
\hline
\end{tabular}

weak concentrations of glyphosate in contact with the soils (maximum $60.13 \mathrm{mg} / \mathrm{L}$ ) in our study.

The $\mathrm{K}_{\mathrm{f}}$ parameter of the Freundlich model, which is the slope of the sorption isotherm, expresses soil sorption capacity for a given range of glyphosate concentrations. In our study, $\mathrm{K}_{\mathrm{f}}$ values ranged from 16.6 for the clay loam soil, to 33.6 for the silt clay loam soil, and 34.5 for the sandy loam soil (Fig. 2). The highest $\mathrm{K}_{\mathrm{f}}$ values were observed in the silt clay loam soil ( $\mathrm{pH}$ 6.3) and sandy loam soil ( $\mathrm{pH} 5.1$ ) which are acid soils, in particular in the sandy loam soil. In spite of the high organic matter content of the clay loam soil and the presence of clay and iron in various forms, $\mathrm{K}_{\mathrm{f}}$ was only 16.6. This was probably due to its basic $\mathrm{pH}$ which led to the dissociation of acid functional groups of the soil and the glyphosate, thus reducing the possibility of hydrogen bonds (McConnell and Hossner, 1985). In the three soils we studied, $\mathrm{pH}$ appeared to be a determining factor in the adsorption of glyphosate.

\subsection{Desorption behaviour of glyphosate}

In addition to sorption experiments that provide information about the amounts of product retained by soil, very interesting knowledge is provided by desorption because it controls the probability of glyphosate returning to the water phase where it can be degraded and/or leached. The samples of soil containing adsorbed glyphosate were thus subjected to five successive desorption steps with $\mathrm{CaCl}_{2} 0.01 \mathrm{M}$.

Our experimental data showed that desorption was only slight. Approximately 6, 7 and $23 \%$ of initially sorbed glyphosate were desorbed from the silt clay loam, sandy loam and clay loam soils, respectively, during the five successive desorption steps (Tab. II). These values indicate a strong hysteresis, in particular in the two acid soils. Hysteresis is evi- denced by an increase in the difference between the adsorption and desorption isotherm slopes and has been well documented (Worrall et al., 2001). The desorbed percentages decreased during the four last desorption steps, perhaps because desorption concerned residues with stronger soil-glyphosate interactions, or because the sorption sites were less accessible to $\mathrm{CaCl}_{2}$. The difference in quantities desorbed from the different soils was related to the acid or basic $\mathrm{pH}$ and not to the initial quantity of glyphosate adsorbed on the soil: we observed the same rate of desorption for the two acid soils although they had a very different $\mathrm{pH}$ (Tab. II). However, if we only took the 1st desorption into account, there was not only a marked difference between acid or basic soil, but also between the two acid soils. At pH 5.1 (2.49\%), desorption was nearly twice as high as at $\mathrm{pH} 6.3(1.5 \%)$. This indicates that parameters other than $\mathrm{pH}$ influence the nature of the bonds between glyphosate and the soil.

However, a principal component analysis did not make it possible to establish a correlation with other physicochemical characteristics of the soils. The experiment enabled us to conclude that (1) sorption increases when the $\mathrm{pH}$ changes from basic to acid but is not proportional to acidity $\left(\mathrm{K}_{\mathrm{f}}\right.$ ranged from 16.6 for clay soil, 33.6 for clay loam soil and 34.5 for sandy loam soil); (2) the $\mathrm{pH}$ is not the only parameter that affects sorption, and (3) desorption is easier when the $\mathrm{pH}$ is basic, but we were unable to identify a direct relation between the acidity of the soil and its ability to desorb glyphosate.

\subsection{Leaching of ${ }^{14} \mathrm{C}$-glyphosate residues}

Cumulated rainfall for the period between 24 March 2005 and 20 February 2006 was 869 mm (Fig. 3). Rainfall distribution was regular, particularly during the periods from 


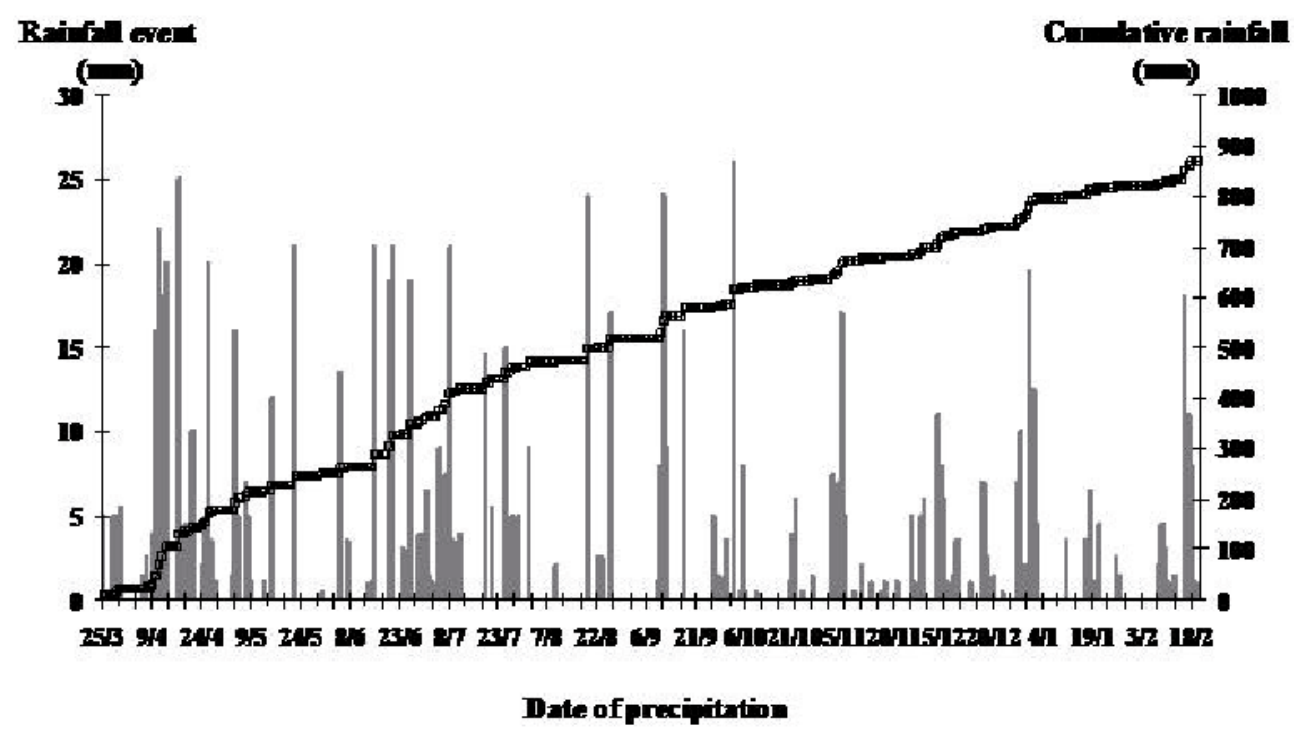

Figure 3. Rainfall events ( $\mathrm{mm}$ ) and cumulated precipitation ( $\mathrm{mm}$ ) during the course of the experiment (March 2005 to February 2006).

24 March to 25 July and from 1 st November to 20 February. This regular rainfall ensured the soil was permanently

wet enough to enable degradation. The average heights of percolated water were $515.9 \mathrm{~mm}$ for the silt clay loam, $382 \mathrm{~mm}$ for the clay loam soil and $375 \mathrm{~mm}$ for the sandy loam soil, i.e., respectively, $59.4,43.95$ and $43.15 \%$ of total precipitation. These values show that restitution by the clay loam soil and sandy loam soil was similar even though their texture and their initial infiltration rate were very different: $103.7 \pm 21.8$, $139.6 \pm 34.9$ and $151.8 \pm 44.1 \mathrm{~cm} \mathrm{~d}^{-1}$ for sandy loam, silt clay loam and clay loam, respectively. The clay loam soil and sandy loam soil produced 19 percolates each while the silt clay loam produced 22.

Contrary to the observations reported by Dousset et al. (2004), in our study the glyphosate residues were present in the first percolation of all three soils 18 days after application of the herbicide (Fig. 4), cumulated rainfall at that time being $84.5 \mathrm{~mm}$ (Fig. 3). The presence of glyphosate in the first percolate indicated leaching by preferential flow (Laitinen et al., 2006). The average volumes percolated by the columns of each soil were very similar ( 257 to $262 \mathrm{~mL}$ ) but the concentrations of the residues were very different: $2.91 \pm 0.75 \mu \mathrm{g} / \mathrm{L}$ for the clay loam soil, $1.53 \pm 0.32 \mu \mathrm{g} / \mathrm{L}$ for the silt clay loam soil and $0.489 \pm 0.151 \mu \mathrm{g} / \mathrm{L}$, for the sandy loam soil.

The sandy loam soil also displayed a strong sorption capacity $\left(\mathrm{K}_{\mathrm{f}} 34.5\right)$ and a fine homogeneous structure at the time of removal, implying low exports. With almost the same sorption/desorption capacity, the quantities leached by the silt clay loam soil $\left(\mathrm{K}_{\mathrm{f}} 33.6\right)$ were nearly three times as high, but varied more from one column to another. This indicated preferential circulation of the residues favoured by the coarse polyhedric structure of this soil. Lastly, the clay loam soil, which combines weak sorption $\left(\mathrm{K}_{\mathrm{f}} 16.6\right)$, major desorption capacity $(21.5 \%)$ and a coarse structure similar to the silt clay loam soil that favours preferential flows, displayed an average of three times more exports than the silt sandy loam soil, and marked variability from one column to another (Fig. 4). After the first percolate, the average residue concentrations of the leachates of the three soils increased gradually to reach a maximum on the $06 / 06 / 05$ for the sandy loam soil and the clay loam soil at, respectively, $5.25 \pm 3.252$ and $15.97 \pm 4.61 \mu \mathrm{g} / \mathrm{L}$. The silt clay loam soil reached a maximum concentration later, on $22 / 07 / 05$, with $9.55 \pm 6.98 \mu \mathrm{g} / \mathrm{L}$. These high concentrations were observed in all cases for leachates of very low volume ( 5 to $20 \mathrm{~mL}$ ), but paradoxically at a period when few residues remained in the soil: approximately $50 \%$ for sandy loam soil, $30 \%$ for the silt clay soil and only $16 \%$ for the clay loam soil. However, these concentrations were much lower than those obtained by De Jonge et al. (2000). Thereafter, the concentration decreased considerably in all leachates but nevertheless remained higher than the European standard of $0.1 \mu \mathrm{g} / \mathrm{L}$. The presence of glyphosate in the leachates 11 months after treatment is in agreement with results obtained by Newton et al. (1994) and Roy et al. (1989). Globally, the quantities of residues leached, expressed in $\mu \mathrm{g}$ glyphosate equivalent, are low, lower than the values given by Fomsgaard et al. (2003): clay loam soil $(4.553 \mu \mathrm{g})>$ silt clay loam soil $(3.256 \mu \mathrm{g})>$ sandy loam soil $(1.84 \mu \mathrm{g})$. However, if these values are expressed as a percentage of the amount applied, i.e. $0.28,0.20$ and $0.11 \%$, respectively, they are higher than those given by Fomsgaard et al. (2003) and Dousset et al. (2004). It should be noted that in the silt clay loam soil, whose sorption/desorption capacity is similar to that of the sandy loam soil, glyphosate leaching was very close to that observed in the clay loam soil, which displayed considerably less sorption capacity.

The physical soil properties that facilitate rapid circulation of water can thus influence the sorption effect. In this study, the potential pollution of the silt clay loam and sandy loam soil, estimated on the basis of their sorption/desorption capacity, should have been extremely close. Among their physical characteristics, only their structural properties differ, and the circulation of water was most rapid in the silt clay loam 


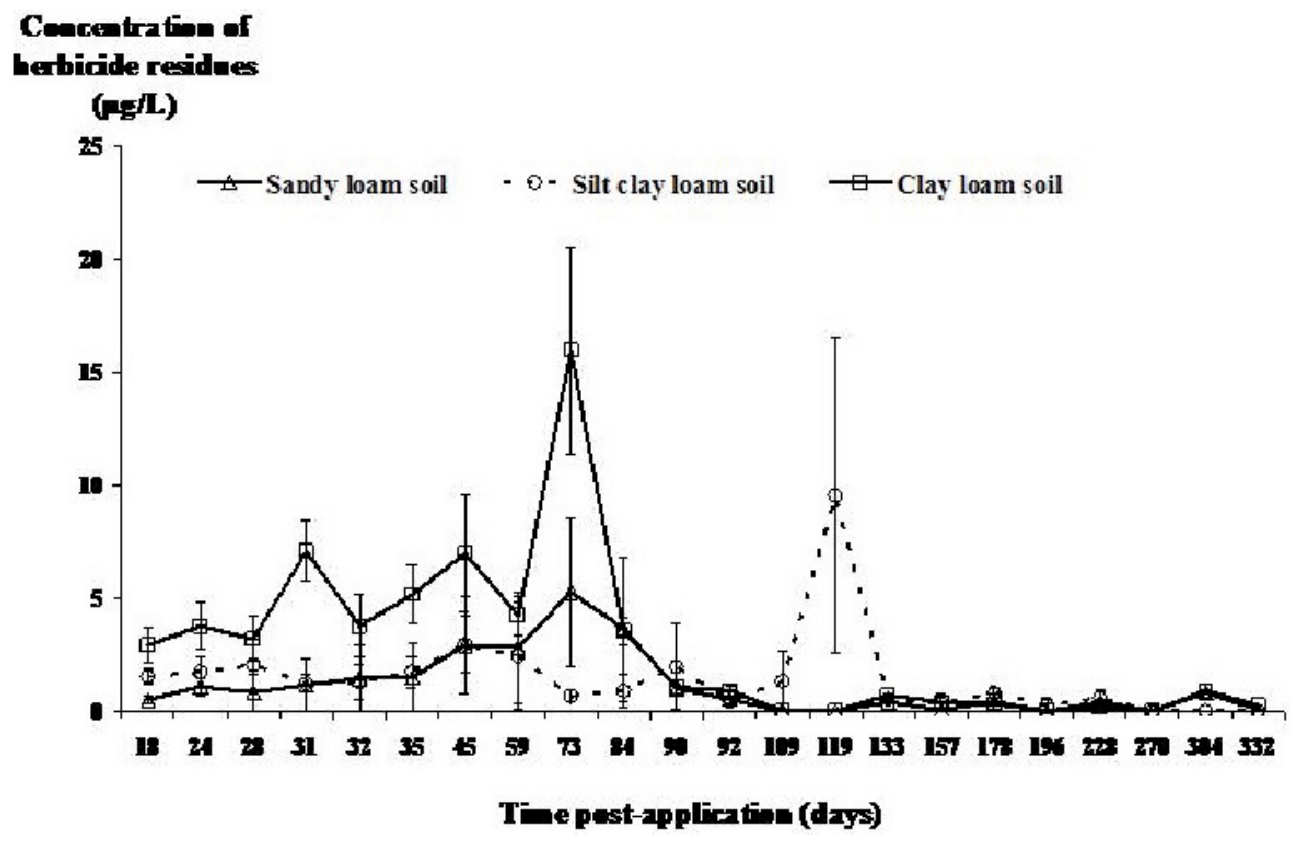

Figure 4. Concentrations of glyphosate residues in the leachates of the three types of soil columns.

soil $(103.7 \pm 21.8$ for sandy loam, $139.6 \pm 34.9$ for silt clay loam and $151.8 \pm 44.1 \mathrm{~cm} \mathrm{~d}^{-1}$ for clay loam). Moreover, rapid circulation is likely to facilitate transport in adsorbed form (De Jonge et al., 2000).

However, pollution potential also depends on the capacity of the soils to degrade and mineralise glyphosate. The half-life of dissipation of the extractable glyphosate in these three soils was very different (see results presented in Sect. 3.4 above), i.e. during incubation at $20^{\circ} \mathrm{C}$, approximately four days for the clay loam soil, 14 days for the silt clay loam soil and 19 days for the sandy loam soil. This implies that, under our conditions, the quantity of residues (glyphosate and AMPA) present on the surface of the soil and available for transfer decreased considerably; more rapidly in clay loam soil than in sandy loam soil, which favoured biodegradation. Thus, the pollution capacity of a clay loam soil was compensated for by its strong mineralisation capacity. The climatic conditions observed during the period between the treatment and the first leachate (average temperature: $10.5^{\circ} \mathrm{C}$, min: $6.0^{\circ} \mathrm{C}$, max: $15.1^{\circ} \mathrm{C}$, and constant moisture) were likely to reduce the possibility of leaching in the clay loam soil and in the silt clay loam soil. Moreover, degradation results in the presence of products such as AMPA and/or sarcosine, whose adsorption/desorption capacity differs from that of glyphosate. Analysis of the leachates did not enable us to identify sarcosine (time of retention identical to co-eluted organic compounds) but did reveal the prevalence of AMPA residues in the leachates (Tab. III).

In the first leachate, AMPA represented $100 \%$ of the residues leached in the clay loam soil but only $45.8 \%$ in the silt clay soil and $36.7 \%$ in the sandy loam soil. Thus, biodegradation - which is influenced by adsorption/desorption of the herbicide but also by the edaphic conditions that determine
Table III. Percentage of glyphosate and aminomethylphosphonic acid (AMPA) residues in the leachates of the three soil types: sandy loam soil, silt clay loam soil and clay loam soil.

\begin{tabular}{lcccccc}
\hline \multicolumn{3}{c}{ Sandy loam soil } & \multicolumn{3}{c}{ Silt clay loam soil } & \multicolumn{3}{c}{ Clay loam soil } \\
Days after Glyphosate & AMPA & \multicolumn{2}{c}{ Glyphosate } & AMPA & Glyphosate & AMPA \\
treatment & $\%$ & $\%$ & $\%$ & $\%$ & $\%$ & $\%$ \\
\hline 18 & 63.3 & 36.7 & 54.2 & 45.8 & 0 & 100 \\
31 & 100 & nd & 29.8 & 70.2 & 0 & 100 \\
35 & 27.6 & 72.4 & 27.6 & 72.4 & 78.9 & 21.1 \\
45 & 92.1 & 7.9 & nd & nd & 51.4 & 48.6 \\
73 & 98.6 & 1,4 & nd & 100 & 0 & 100 \\
84 & 98.8 & 1.2 & nd & 100 & 0 & 100 \\
92 & 94.9 & 5,1 & nd & 100 & nd & nd \\
133 & 75 & 25 & 44.6 & 55.4 & 52.7 & 47.3 \\
157 & 80.9 & 19.1 & nd & nd & nd & nd \\
178 & 0 & 100 & nd & 100 & nd & 100 \\
196 & - & - & nd & 100 & - & - \\
332 & 0 & 100 & nd & 100 & 0 & 100 \\
\hline
\end{tabular}

nd: below the limit of detection.

microflora activity - can strongly influence not only the degree of pollution of the soil by the pesticide but also the nature of the pollution.

\subsection{Distribution of glyphosate residues in the soils}

One column of each soil was removed at different dates. Examination of the distribution of the residues enabled us to determine the half-life of the glyphosate and its mode of transport in the columns of soil in our climatic conditions. Table IV shows the results of the analyses carried out on only one column of each soil removed at the date indicated. The standard 
Table IV. Distribution profile of extractable and non-extractable residues of glyphosate during the course of the experiment in the three soils.

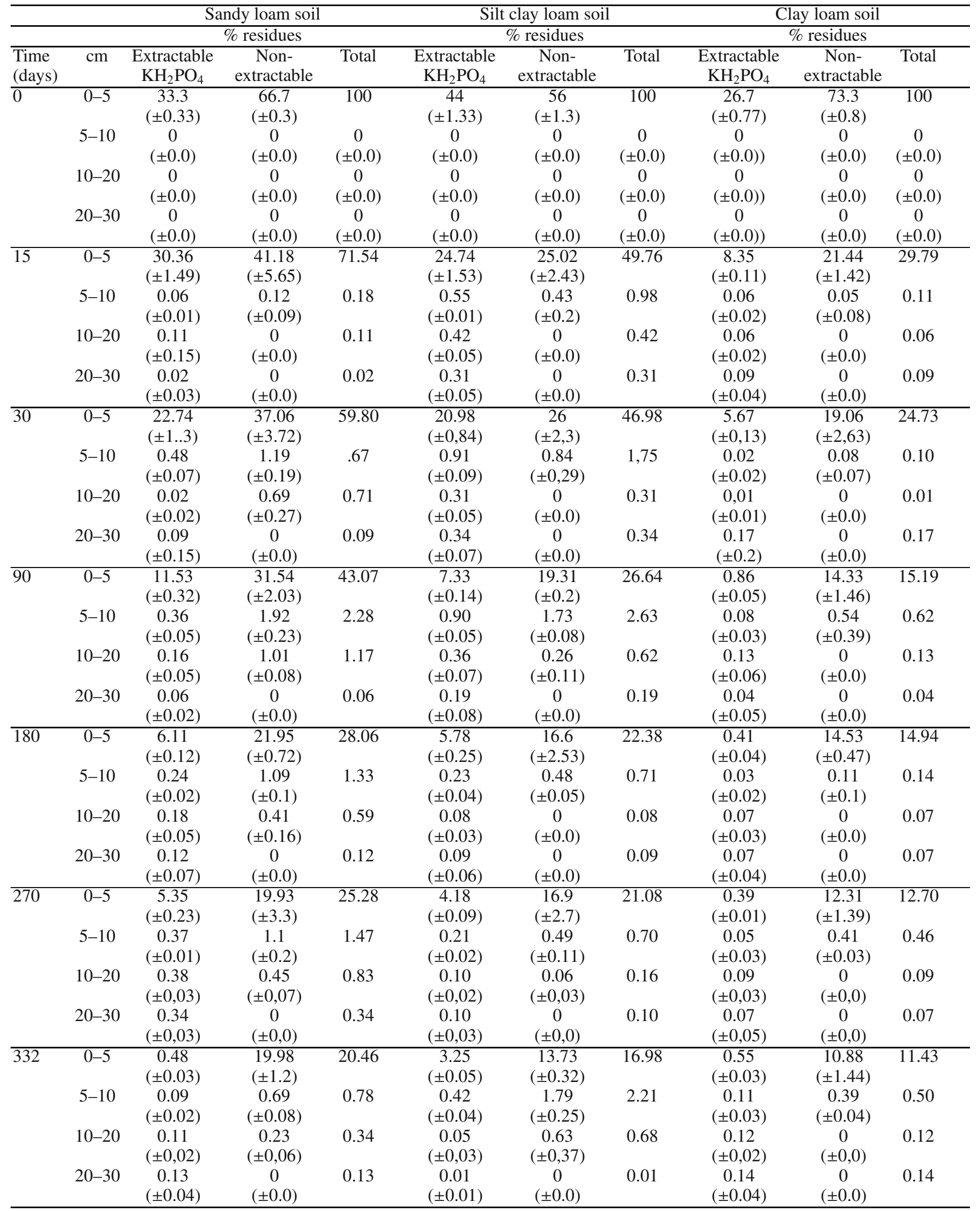


deviations relate to the measuring accuracy for a given level and the averages indicated do not reflect the heterogeneity of columns of the same soil.

The results obtained 15 days after treatment showed an extremely large reduction in the total residues present in the soil columns. Only $71.85,51.47$ and $30.05 \%$ of the radioactivity applied was found in sandy loam, silt clay loam and clay loam soil, respectively. Over the course of time, the residues in the soils decreased and the difference between each type of soil also decreased: 332 days after treatment the total radioactivity present was only $21.71,19.88$ and $12.19 \%$, respectively. This reduction in residues was mainly due to mineralisation of the glyphosate, as this product is not volatile and leaching represented less than $0.3 \%$ of the total glyphosate applied.

When we considered only water-extractable residues these being likely to cause contamination of the water that passes through the soil - we observed that 15 days after the treatment, they represented $42.5 \%$ of the total residues present in sandy loam soil, $50.5 \%$ in the silt clay loam and $28.5 \%$ in the clay loam soil. Although the clay loam soil had the smallest quantity of total residues and the weakest rate of extractable residues, it had the highest concentration of residues in the leachates. This underlines the importance, not of the process of adsorption/desorption - which should provide information about the quantity of residues available for transport - but perhaps of the mode of circulation of the water in the soil.

The amount of extractable residues compared with total residues present in each type of soil decreased over time. Despite this decrease, the level of contamination of the leachates remained constant and even progressed, and the highest concentrations of residues in the leachates were observed 70 and 120 days after application of the herbicide, whereas the total and extractable residues represented only a small percentage of the total amount of glyphosate applied (46.58, 30.08 and $15.98 \%$ in total residues and $12.11,8.78$ and $1.11 \%$ in extractable residues for sandy loam, silt clay loam and the clay loam soil, respectively). These results are in disagreement with those of Rueppel et al. (1977) and Roy et al. (1989), who reported that glyphosate can be considered as essentially nonleachable in the soil.

Our results also emphasise the determining role of water circulation in the soil column. In fact, depending on structural modifications over time, loss of macroporosity may have occurred on the surface of the soil columns, thus slowing infiltration at the level where most residues were present, which, in turn, could facilitate desorption.

The presence of residues in the first leachates of the columns led us to consider the hypothesis of circulation of the residues by preferential flow. Examination of the distribution of the residues in the profile of the soil columns confirmed this mode of transport. Whatever the soil, we observed that up to 15 days after treatment, from 95.1 to $99.6 \%$ of the residues were located in the top $0-5 \mathrm{~cm}$ layer and that only traces were present in the lower layers. This supports the hypothesis of preferential circulation; the residues desorbed at the surface were only partially adsorbed by the soil at lower levels because of the low surface contact between soil and water and the rapid circulation of the water, which prevents equilibrium being reached. At 30 and especially 90 days after treatment, although total residues had decreased in the column, we observed a significant increase in residues in the top 5-10 cm. These results are in agreement with those of Roy et al. (1989), who found no detectable residues of glyphosate or AMPA in the 15-30 cm layer of two soils under outdoor conditions after 335 days of treatment. However, this increase in residues in the 5-10 cm layer could indicate redistribution due to circulation of water by fine porosity (chromatography flow).

Finally, we would like to underline the particular place of the non-extractable residues, with the $\mathrm{KH}_{2} \mathrm{PO}_{4}$. Large quantities of non-extractable residues formed immediately after time 0 . Shortly after application of glyphosate they accounted for $66.7 \%$ in sandy loam, $56 \%$ in silt clay loam and $73.3 \%$ in clay loam soil. After 15 days, these values dropped to 41.2, 25 and $21.4 \%$ and then gradually decreased to $20.9,16.2$ and $11.3 \%$ of the total amount of glyphosate applied. The large quantity of non-extractable residues immediately formed suggests that the herbicide moves in spaces that are not accessible to $\mathrm{KH}_{2} \mathrm{PO}_{4}$, either during capillary invasion by water of the solution initially applied on dry soil, or due to the action of diffusion. However, the role of diffusion is less probable in such a short time (T0). The rate of formation of non-extractable residues thus very probably depends on soil moisture at the time of the treatment.

The very slow decrease in the concentration of nonextractable residues in the soil over time means that they are likely to again become extractable and/or available for degradation by soil micro-organisms and for transport by water. This reversibility would explain the presence of residues in the leachates at relatively high concentrations even 11 months after application. From the point of view of the protection of water quality, where contamination is caused by glyphosate, AMPA, or perhaps sarcosine, our results showed that the persistence value that needs to be taken into account is that which refers to total residues in the soil, and not the value based on analysis of extractable glyphosate.

In our work, which was based on ${ }^{14} \mathrm{C}$-phosphonomethyl glyphosate, it was only possible to take into account AMPA, whose mineralisation half-life was 81 days for sandy loam, 37 days for silt clay loam and 10 days for clay loam soil. In the same soils, but incubated at $20^{\circ} \mathrm{C}$, its half-life was 43 days in sandy loam, 32 days in silt clay loam and 14 days in clay loam soil, and the half-life of water-extractable glyphosate was only 19, 14 and 4 days (results not shown).

Our results showed that mineralisation of glyphosate was particularly rapid in the clay loam soil, certainly due to its $\mathrm{pH}$, which was responsible for reduced retention and easy desorption, but also favourable for bacterial activity. The reverse was observed in sandy loam soil, whose acid pH was unfavourable for bacterial activity and which displayed a high retention rate of glyphosate.

\section{CONCLUSION}

Compared with other herbicides such as sulcotrione and metamitron (Mamy and Barriuso, 2005), glyphosate is 
strongly adsorbed even in soils with a basic $\mathrm{pH}$. In our study, $\mathrm{K}_{\mathrm{f}}$ values were very high: $34.5,33.6$ and 16.6 for soil $\mathrm{pH}$ of 5.1, 6.3 and 7.9, respectively. More interesting still, in comparison with the risks of water pollution, the desorption is slow and slight. Approximately 6, 7 and $23 \%$ of initially sorbed glyphosate were desorbed from the silt clay loam, sandy loam and clay loam soils, respectively, during the five successive desorption steps. The adsorption and desorption processes are affected by $\mathrm{pH}$, but the $\mathrm{pH}$ is not the only parameter that affects sorption and desorption.

Under an oceanic climate, which is favourable for degradation, leaching was limited. Expressed as a percentage of the amount applied and in our experimental conditions, values are $0.28 \%$ for the clay loam soil, $0.20 \%$ for the silty clay loam soil and $0.11 \%$ for the sandy loam soil. Yet, despite this low leaching, the residue concentrations of the leachates remained for 11 months higher than the European standard of $0.1 \mu \mathrm{g} / \mathrm{L}$. However, contamination of the water resource was primarily due to its metabolite, AMPA. The extent of the leaching of the residues under outdoor conditions was not directly linked with adsorption/desorption. In fact, in two of the soils (sandy loam and silt clay loam) which displayed the same glyphosate adsorption/desorption capacity but different textural and structural characteristics, the increase in leaching was twice as high in the silt clay loam than in the sandy loam soil over a period of one year. The mode of circulation of water in the soil (importance of preferential flow), the type of transport (soluble and/or adsorbed form) and the intensity of biodegradation (degrading microbial biomass, moisture, temperature) thus strongly influence the rate of transport and the nature of the compounds transported by water. In addition, when adsorption of glyphosate is relatively low with easy desorption (clay loam), intense biodegradation then contributes to reducing leaching and hence contamination of soil water. In spite of short half-lives, the contamination of water continues for a period of more than one year, and this needs to be taken into consideration in the context of the large quantities of sequestered residues formed by glyphosate immediately after initial treatment. These residues, which were trapped in the soil matrix and thus not accessible to $\mathrm{KH}_{2} \mathrm{PO}_{4} 0.1 \mathrm{M}$, probably contributed to the maintenance of the contamination of leachates.

Acknowledgements: The authors thank the DIREN, AERM and the DRAF of Lorraine for their financial support.

\section{REFERENCES}

Autio S., Siimes K., Laitinen P., Ramo S., Oinonen S., Eronen L. (2004) Adsorption of sugar beet herbicides to Finnish soils, Chemosphere $55,215-226$.

Batjes N.H. (1998) World Reference Base for Soil Resources, ISRIC, FAO, ISSS ${ }^{\circledR}$ and Acco, Leuven, Belgium.

Cheah U.B., Kirkwood R.C., Lum K.Y. (1997) Adsorption, desorption and mobility of four commonly used pesticides in malaysian agricultural soils, Pestic. Sci. 50, 53-63.

Chiou C.T., Kile D.E., Rutherford D.W., Sheng G., Boyd S.A. (2000) Sorption of selected organic compounds from water to a peat soil and its humid-acid and humin fractions: potential sources of the sorption nonlinearity, Environ. Sci. Technol. 34, 1254-1258.

Coquet Y. (2002) Variation of pesticides sorption isotherm in soil at the catchment scale, Pest. Manag. Sci. 58, 69-78.

De Jonge H., De Jonge L.W. (1999) Influence of pH and solution composition on the sorption of glyphosate and prochloraz to a sandy loam soil, Chemosphere 39, 753-763.

De Jonge H., De Jonge L.W., Jacobsen O.H. (2000) $\left[{ }^{14} \mathrm{C}\right]$ Glyphosate transport in undisturbed topsoil columns, Pest. Manag. Sci. 56, 909-915.

Doliner L.H. (1991) Emploi avant récolte du glyphosate (RoundupMD), Document de travail, Agriculture Canada, Direction des pesticides, $107 \mathrm{p}$.

Dousset S., Chauvin C., Durlet P., Thévenot M. (2004) Transfert of hexazinone and glyphosate through undisturbed soil columns in soils under Christmas tree cultivation, Chemosphere 57, 265-272.

Fomsgaard I.S., Spliid N.H., Felding G. (2003) Leaching of pesticides through normal-tillage and low-tillage soil lysimeter study. 2. Glyphosate, J. Environ. Sci. Heal. B 38, 19-35.

Glass R.L. (1987) Adsorption of glyphosate by soils and clay minerals, J. Agr. Food Chem. 35, 497-500.

Guennelon R. (1994) Le sol et l'eau, in: Bonneau M., Souchier B. (Eds.), Pédologie 2. Constituants et propriétés du sol, Masson, Paris, pp. 395-428.

IFEN (2006) The pesticides in the water, data of 2003 and 2004, Rapport of French Institute of the Environment, Orleans, France, $40 \mathrm{p}$.

Kjaer J., Olsen P., Ullum M., Grant R. (2005) Leaching of glyphosate and amino-methylphosphonic acid from danish agricultural field sites, J. Environ. Qual. 34, 403-407.

Jacquin F., Florentin L. (1988) Atlas des sols de lorraine, Nancy, 133 p.

Laitinen P., Siimes K., Eronen L., Ramo S., Welling L., Oinonen S., Mattsoff L., Ruohonen-Lehto M. (2006) Fate of the herbicide glyphosate, glyphosinate-ammonium, phenmedipham, ethofumesate and metamitron in two Finnish arable soils, Pest. Manag. Sci. $62,473-491$.

Mamy L., Bariusso E. (2005) Glyphosate adsorption in soils compared to herbicides replaced with the introduction of glyphosate resistant crops, Chemosphere 61, 844-855.

McConnell J.S., Hossner L.R. (1985) pH-dependent adsorption isotherms of glyphosate, J. Agr. Food Chem. 33, 1075-1078.

Newton M., Horner L.M., Cowell J.E., White D.E., Cole E.C. (1994) Dissipation of glyphosate and aminomethylphosphonic acid in north American forests, J. Agr. Food Chem. 42, 1795-1802.

Roy D.N., Konar S.K., Banerjee S., Charles D.A. (1989) Persistance, movement, and degradation of glyphosate in selected Canadian boreal forest soils, J. Agr. Food Chem. 37, 437-440.

Rueppel M.L., Brightwell B.B., Schaefer J., Marvel J.T. (1977) Metabolism and degradation of glyphosate in soil and water, J. Agr. Food Chem. 25, 517-528.

OECD (2000) OECD guidelines for the testing of chemicals, Adsorption/desorption using a batch equilibrium method, OECD Test Guideline, Vol. 106, OECD Publications, Paris.

Saison C., Perrin-Ganier C., Amellal S., Morel J.L., Schiavon M. (2004) Effect of metals on the adsorption and extractability of ${ }^{14} \mathrm{C}$ phenanthrene in soils, Chemosphere 55, 477-485.

Sprankle P., Meggitt W.F., Penner D. (1975) Adsorption, mobility, and microbial degradation of glyphosate in the Soil, Weed Sci. 23, 229 234.

Worrall F., Fernandez-Perez M., Johnson A.C., Flores-Cesperedes F., Gonzalez-Pradas E. (2001) Limitations on the role of incorporated organic matter in reducing pesticide leaching, J. Contam. Hydrol. $49,241-262$. 